\title{
Earthworms and Fusarium oxysporum: effect on strawberry plant growth and production
}

\section{Minhocas e Fusarium oxysporum: efeito no crescimento e produção do morangueiro}

\author{
Mario Gámiz Infante ${ }^{1}$; Manuel Avilés Guerrero²; Celia Borrero Vega ${ }^{3}$; Wilian Carlo \\ Demetrio $^{4 *}$; Jair Alves Dionísio ${ }^{5}$
}

\begin{abstract}
Earthworms are soil invertebrates that play an important environmental role and are often referred to as "ecosystem engineers". These invertebrates can influence several organisms, from microscopic life forms to plants. Although many works had reported positive effects of earthworms on plant growth, studies combining these invertebrates and soil pathogens showed numerous positive interactions. Fusarium wilt is a global disease that can cause severe damage to strawberry fields. The aim of this study was to evaluate the effects of inoculation of earthworms (Lumbricus terrestris) and Fusarium wilt (Fusarium oxysporum f. sp. fragariae) in strawberry plants. This greenhouse experiment was carried out in the University of Seville School of Agricultural Engineering, Utrera City, Spain. Strawberries (Rooted cuttings) were planted in plastic pots and administered the following treatments: Control (absence of F. oxysporum f. sp. fragariae and earthworms), T1 (absence of $F$. oxysporum f. sp. fragariae, two $L$. terrestris per pot), T2 (inoculum of $F$. oxysporum f. sp. fragariae, absence of L. terrestris), and T3 (inoculum of $F$. oxysporum f. sp. fragariae and two L. terrestris). Weekly fruit production was measured for seven months. After this period the shoot fresh weight and the leaf nutrient content was measured. The results obtained showed no interaction between $L$. terrestris and F. oxysporum f. sp. fragariae on strawberry production. $\mathrm{T} 1$ treatment resulted in fruit production superior to other treatments, including the control. An absence of differences in dry shoot matter was observed with earthworm treatment, and small differences were found in the leaf nutrient content. The earthworm inoculation was unable to suppress the negative effects of Fusarium wilt in strawberry production. However, positive effects such as a reduction in the disease severity were found in the earthworm treated plants. In treatments without F. oxysporum f. sp. fragariae inoculation, the presence of earthworms increased plant productivity by $44.21 \mathrm{~g}$ per pot, compared with the control.
\end{abstract}

Key words: Lumbricus terrestris. Fusarium oxysporum f. sp. fragariae. Interaction. Microorganisms.

\section{Resumo}

Minhocas são invertebrados do solo que participam de importantes funções ambientais e são consideradas "engenheiros do ecossistema". Estes animais podem influenciar diversos organismos, desde formas microscópicas até mesmo plantas. Embora muitos trabalhos citem efeitos positivos da atividade de

1 Discente, Departamento de Ciencias Agroflorestales, Universidad de Sevilla, Sevilla, España. E-mail: mariogamiz93@gmail.com

2 Prof. Dr., Departamento de Ciencias Agroflorestales, Universidad de Sevilla, Sevilla, España. E-mail: aviles@us.es

Dra $^{\mathbf{a}}$, Departamento de Ciencias Agroflorestales, Universidad de Sevilla, Sevilla, España. E-mail: cborrero@us.es

${ }^{4}$ Discente, Curso de Doutorado do Programa de Pós-Gradução em Ciência do Solo, Universidade Federal do Paraná, UFPR, Curitiba, PR, Brasil. E-mail: wiliandemetrio@hotmail.com

5 Prof. Dr., Departamento de Solos e Engenharia Agrícola, UFPR, Curitiba, PR, Brasil. E-mail: jair@ufpr.br

Author for correspondence

Received: Mar. 06, 2017 - Approved: Mar. 12,2018 
minhocas no crescimento das plantas, estudos combinando estes invertebrados e patógenos de solo têm demonstrado inúmeras interações. A murcha-de-fusarium é uma doença mundialmente difundida capaz de causar grandes danos ao morangueiro, e seu controle geralmente é ineficiente. O objetivo deste estudo foi avaliar os efeitos da inoculação de minhocas (Lumbricus terrestris) e murcha de fusarium (Fusarium oxysporum f. sp. fragariae) em plantas de morango. O experimento foi conduzido em ambiente protegido na Escola de Engenharia Agrícola da Universidade de Sevilha, Utrera - Espanha. Plantas de morango (estacas enraizadas) foram plantadas em vasos plásticos e submetidas aos seguintes tratamentos: Controle (ausência de $F$. oxysporum f. sp. fragariae e minhocas), T1 (ausência de $F$. oxysporum f. sp. fragariae, duas L. terrestris por vaso), T2 (inóculo de $F$. oxysporum f. sp. fragariae, ausência de L. terrestris) e T3 (inóculo de F. oxysporum f. sp. fragariae e duas L. terrestris). A produção de frutos foi semanalmente mensurada durante sete meses. Após este período, foram avaliadas a matéria seca da parte aérea e o conteúdo de nutrientes das folhas. Os resultados obtidos não demonstraram entre L. terrestris e F. oxysporum f. sp. fragarie na produção de frutos. Mas, o tratamento T1 apresentou produção superior a todos os outros tratamentos, incluindo o controle. Foram observadas pequenas diferenças no conteúdo de nutrientes das folhas e não se verificou efeito das minhocas na massa seca da parte aérea. A inoculação de minhocas não foi capaz de reduzir os efeitos negativos da murcha de fusarium na produção do morangueiro. Entretanto, foram observados efeitos positivos, tais como redução da severidade da doença. No tratamento sem inóculo de $F$. oxysporum f. sp. fragariae, a presença de minhocas aumentou a produtividade das plantas em 44,21 g por vaso, comparado com o tratamento controle.

Palavras-chave: Lumbricus terrestris. Fusarium oxysporum f. sp. fragariae. Interação. Microrganismos.

\section{Introduction}

Earthworms are keystone organisms in the environment, and together with ants and termites are denominated "ecosystem engineers" (LAVELLE et al., 1997). The living habit of these organisms can modify soil chemical, physical, and biological characteristics (BROWN et al., 2000). Moreover, these invertebrates also interact with other organisms; several studies have reported positive effects of earthworms on plant growth (GROENIGEN et al., 2014). However, the importance of earthworms in diseased plants demonstrates numerous interactions whose results are dependent on the invertebrate species, plant and pathogen considered (ELMER, 2009; LAFONT et al., 2007).

Earthworms are distributed throughout Europe (RUTGERS et al., 2016). Lumbricus terrestris is an important earthworm species found on the continent, mainly in temperate regions and living in natural and agricultural sites. Data regarding soil invertebrate communities in Spain are scarce, but $L$. terrestris in agricultural systems, including strawberry fields has been previously studied (KUKKONEN et al., 2006).
The strawberry (Fragaria $\times$ ananassa) is a fruit appreciated worldwide. Global production is around 8.1 million $\mathrm{Mg}$ with Asia responsible for $48 \%$ of this total. In 2014, Spain produced 291,870 Mg of strawberries (7,790 ha), 44\% more than Poland, the second biggest producer in Europe (FAO, 2017). Several diseases can reduce strawberry productivity, but Fusarium wilt has received special attention. Fusarium oxysporum is a globally distributed soil pathogen with several host-plants (KOIKE; GORDON, 2015). The damage caused by this microorganism is variable and dependent upon several conditions, but losses of $60 \%$ in strawberry fields have been reported in Australia (GOLZAR et al., 2007). The difficulties of Fusarium wilt control are similar to those found with other soil pathogens (high costs and inefficient control) and represent a barrier to increasing agricultural productivity (STRAUSS; KLUEPFEL, 2015). Studies with alternative management to control soil pathogens have increased in recent years, probably due to increased interest in sustainable agriculture.

The employment of good agricultural practices, such decreased soil disturbance and reductions in 
pesticide application, has increased earthworm populations in agricultural fields around the world, but little is known about the effects of these belowground invertebrates on strawberry plants (CRITTENDEN et al., 2014). Thus, the aim of this study was to evaluate the effects of interactions between $L$. terrestris and $F$. oxysporum f. sp. fragariae on strawberry growth and production in Utrera city, Spain.

\section{Material and Methods}

\section{Study description}

The greenhouse experiment was carried at the University of Seville School of Agricultural Engineering (USSAE), Utrera city, Spain. Strawberry plants were used in a factorial experiment with a completely randomized design, with four treatments and five replicates. The treatments were: control (absence of F. oxysporum f. sp. fragariae and earthworms); T1 (absence of $F$. oxysporum f. sp. fragariae, two $L$. terrestris per pot); T2 (Inoculum of $F$. oxysporum $\mathrm{f}$. sp. fragariae, absence of L. terrestris); T3 (Inoculum of F. oxysporum $\mathrm{f}$. $\mathrm{sp}$. fragariae and two L. terrestris per pot).

The microcosms utilized were plastic pots with 2.8-L capacity. Each one received a mixture (Mix) of the substrate (Kekkilä Brown 025W), sand, and soil (1:1:1 proportion). Afterward, chemical analysis was performed, which showed the following characteristics: $\mathrm{pH}_{\text {water }} 7.09 ; \mathrm{C}_{\text {org }} 34.4 \mathrm{~g}$ $\mathrm{dm}^{-3}$; water soluble P $14.91 \mathrm{mg} \mathrm{kg}^{-1} ; \mathrm{Ca}^{2+} 0.24 \mathrm{cmol}_{\mathrm{c}}$ $\mathrm{kg}^{-1} ; \mathrm{Mg}^{2+} 0.18 \mathrm{cmol}_{\mathrm{c}} \mathrm{kg}^{-1} ; \mathrm{K}^{+} 0.16 \mathrm{cmol}_{\mathrm{c}} \mathrm{kg}^{-1} ; \mathrm{Na}^{+}$ $0.08 \mathrm{cmol}_{\mathrm{c}} \mathrm{kg}^{-1}$; Fe $10.29 \mathrm{mg} \mathrm{kg}^{-1}$; Mn $1.42 \mathrm{mg} \mathrm{kg}^{-1}$; $\mathrm{Cu} 0.34 \mathrm{mg} \mathrm{kg}^{-1} ; \mathrm{Zn} 1.90 \mathrm{mg} \mathrm{kg}^{-1}$ (AUSTRALIAN STANDARD, 1993).

The earthworm species used in this study was Lumbricus terrestris, collected in a wheat crop under a no-tillage system in Alcalá de Guadaíra, Seville city. Adults (clitellum present) were identified using the external morphology according to Moreno (2004). Before inoculation, the earthworms were placed in pots containing the same substrate mixture for seven days to allow acclimation and cleansing of the intestinal tract. Strawberries (rooted cuttings) were planted in pots containing $3.0 \mathrm{Kg}$ of Mix, and the earthworms were inoculated in the experimental units ten days after the planting. Prior to inoculation, earthworm weights were measured (grams per individual) to allow maintenance of a similar biomass between the replicates.

To obtain the inoculum of Fusarium oxysporum f. sp. fragariae, we utilized contaminated strawberry plants from Huelva province. The fungal isolates were identified by Borrero et al. (2017) using molecular techniques proposed by Suga et al. (2013). After inoculation, the plants were stored in the vegetable sanitation laboratory of USSAE. To acquire a satisfactory population of $F$. oxysporum f. sp. fragariae, the material was replicated in 50 Petri dishes using AMAP culture media (medium composed of $10 \mathrm{~g} \mathrm{~L}^{-1}$ Agar, $10 \mathrm{~g} \mathrm{~L}^{-1}$ Malt extract, $2 \mathrm{~g} \mathrm{~L}^{-1}$ Asparagine and $0.5 \mathrm{~g} \mathrm{~L}^{-1}$ Peter's foliar feed 27-15-12/ $-\mathrm{P}_{2} \mathrm{O}_{5}-\mathrm{K}_{2} \mathrm{O}+$ micronutrients) (BORRERO et al., 2009) at $25{ }^{\circ} \mathrm{C}$ for seven days. Next, water was used to homogenize the suspension, then $0.1 \mathrm{~mL}$ was transferred to a Neubauer chamber to determine cell concentration. The inoculations of $F$. oxysporum f. sp. fragariae was performed in four periods (Table 1), and the pathogen dosages were inoculated following dilution in water (soil field capacity). The fertirrigation was realized daily, intercalating the application of Peter's foliar feed $\left(1.0 \mathrm{~g} \mathrm{~L}^{-1}\right)$, urea $\left(0.3 \mathrm{~g} \mathrm{~L}^{-1}\right)$ and magnesium sulfate $\left(0.7 \mathrm{~g} \mathrm{~L}^{-1}\right.$ of $\left.\mathrm{MgSO}_{4} 7 \mathrm{H}_{2} \mathrm{O}\right)$ with $0.7 \mathrm{~g}$ of calcium chlorate $\left(\mathrm{CaCl}_{2} 2 \mathrm{H}_{2} \mathrm{O}\right)+0.19 \mathrm{~g}$ of Sequestrene ${ }^{\circledR} 138$ $\mathrm{Fe} \mathrm{G} 1006 \%$ in the other. 
Table 1. Date, isolates and concentration of inoculum of Fusarium oxysporum f. sp. fragarie inoculated in strawberry plants.

\begin{tabular}{cccc}
\hline Inoculation & Date & $\begin{array}{c}\text { Isolates of Fusarium oxysporum } \\
\text { f. sp. fragarie }\end{array}$ & $\begin{array}{c}\text { Concentration (colony-forming unit } \mathrm{ml}^{-1} \\
\text { substrate) }\end{array}$ \\
\hline $1^{\text {a }}$ & $17 / 12 / 2015$ & F74, F77, F79 & $2.1 \times 10^{5}$ \\
$2^{\text {a }}$ & $18 / 02 / 2016$ & F74, F77, F79 & $1.8 \times 10^{5}$ \\
$3^{\text {a }}$ & $07 / 04 / 2016$ & F75, F78, F79 & $2.0 \times 10^{5}$ \\
$4^{\text {a }}$ & $15 / 04 / 2016$ & F74, F77, F79 & $2.2 \times 10^{5}$ \\
\hline
\end{tabular}

\section{Variables measured}

To evaluate production, mature fruits were collected from each pot once a week, and the fresh weight measured using a digital balance (decimal precision). The accumulated production was calculated by adding the productivity obtained in one week plus the production of the previous week. At the end of the experiment, the disease severity was evaluated and was given a score based on a symptom severity scale where: $0=$ plant welldeveloped, with no disease symptoms; $1=1-25 \%$ plants with wilted or dead leaves; $2=26-50 \%$ plants with wilted or dead leaves; $3=51-75 \%$ plants with wilted or dead leaves; $4=76-100 \%$ plants with wilted or dead leaves; 5 = plant death (FANG et al., 2011). Disease ratings were made relative to control plants. In addition, the density of $F$. oxysporum $\mathrm{f}$. sp. fragariae was determined according to Borrero et al. (2012) with some modifications, were utilized $5 \mathrm{~g}$ of soil re-suspended in $90 \mathrm{~mL}$ of pyrophosphate (TUITERT et al., 1998). After, the strawberry plants were retired (cut above the soil), dried at $60{ }^{\circ} \mathrm{C}$ and weighed (digital balance) to obtain the dry shoot matter. Using a composite sample of five leaves, leaf nutrient content was determined. The elements measured were: P (MURPHY; RILEY, 1962), total $\mathrm{N}$ (Elemental analyzer CNS - 2000), K, S, Ca, Mg, $\mathrm{Na}, \mathrm{Fe}, \mathrm{Mn}, \mathrm{Zn}, \mathrm{Cu}$, and $\mathrm{B}$, using an ICE 3500 atomic absorption spectrometer.

\section{Statistical analysis}

Strawberry production, disease severity, fresh shoot weight, and leaf nutrient content were submitted to Shapiro-Wilk test, and when necessary (non-normal expected distribution), data were transformed using the equation " $\sqrt[3]{x}$ ". Analysis of variance (ANOVA) was performed using Tukey's HSD test $(p<0.05)$. The programs utilized were Statistica $^{\circledR} 10.0$ (STATSOFT, INC., 2011) and SigmaPlot ${ }^{\circledR} 11.0$ (SYSTAT SOFTWARE, INC., 2008).

\section{Results and Discussion}

The inoculation of $F$. oxysporum $\mathrm{f}$. sp. fragariae was effective, and the inoculum density in the plants revealed means between 6,896 and 12,037 colony forming units (CFU) $\mathrm{g}^{-1}$ for both inoculation treatments. Populations were superior to control, where we found only $1,602 \mathrm{CFU} \mathrm{g}^{-1}$. The values of disease severity observed were $40.16 \%$ for T2 (without earthworms), which were significantly superior to T3 (two L. terrestris), which were $28.22 \%$. Some results related to strawberry production did not show differences among the treatments (first two months).

Strawberry production data did not show an interaction between earthworms and $F$. oxysporum f. sp. fragariae, indicating that $L$. terrestris was unable to reduce the negative effects of Fusarium wilt on fruit production. However, positive effects of earthworm presence in the absence of F. oxysporum f. sp. fragariae were observed. The influence of treatments in strawberry production occurred in the last two experimental months 
(Figure 1). In the period from April 8 to May 13, the production had the same distribution pattern, with T1 (two L. terrestris) superior to T2 (F. oxysporum f. sp. fragariae inoculation, Figure 1a, 1b). By May 20, inoculation with two L. terrestris resulted in production of $388.64 \mathrm{~g}$ (Figure 1c), while T2 and T3 produced a total of 325.07 and $352.09 \mathrm{~g}$ of strawberries, respectively. Considering the data distribution in the last four evaluations, it is possible to identify the formation of three data groups: T1, with final strawberry production (accumulated at 24/06) of 485.12 g pot $^{-1}$; control with 440.91 g pot $^{-1}$ and the groups with $F$. oxysporum $\mathrm{f}$. sp. fragariae inoculations, T3 (366.82 g pot $^{-1}$ ) and T2 (343.64 $\mathrm{g}$ pot $\left.^{-1}\right)$. The observed increases in $\mathrm{T} 1$ in relation to control represent around $1,000 \mathrm{~kg}$ per hectare (considering 24,000 strawberry plants hectare ${ }^{-1}$ ).

Figure 1. Accumulated strawberry production (g) from the beginning of the study until final evaluation: a) Until 08 April 2016; b) Until 13 May 2016; c) Until 20 May 2016; d) Until 27 May 2016; e) Until 03 June 2016; f) Until 03 June 2016; g) Until 17 June 2016; h) Until 24 June 2016 in: control (absence of $F$. oxysporum f. sp. fragariae and earthworms), T1 (absence of $F$. oxysporum f. sp. fragariae, two L. terrestris per pot), T2 (Inoculum of $F$. oxysporum f. sp. fragariae, absence of $L$. terrestris), T3 (Inoculum of $F$. oxysporum f. sp. fragariae and two L. terrestris per pot). Different letters above the bars indicate statistical differences $(\mathrm{p}<0.05)$ by Tukey's test.
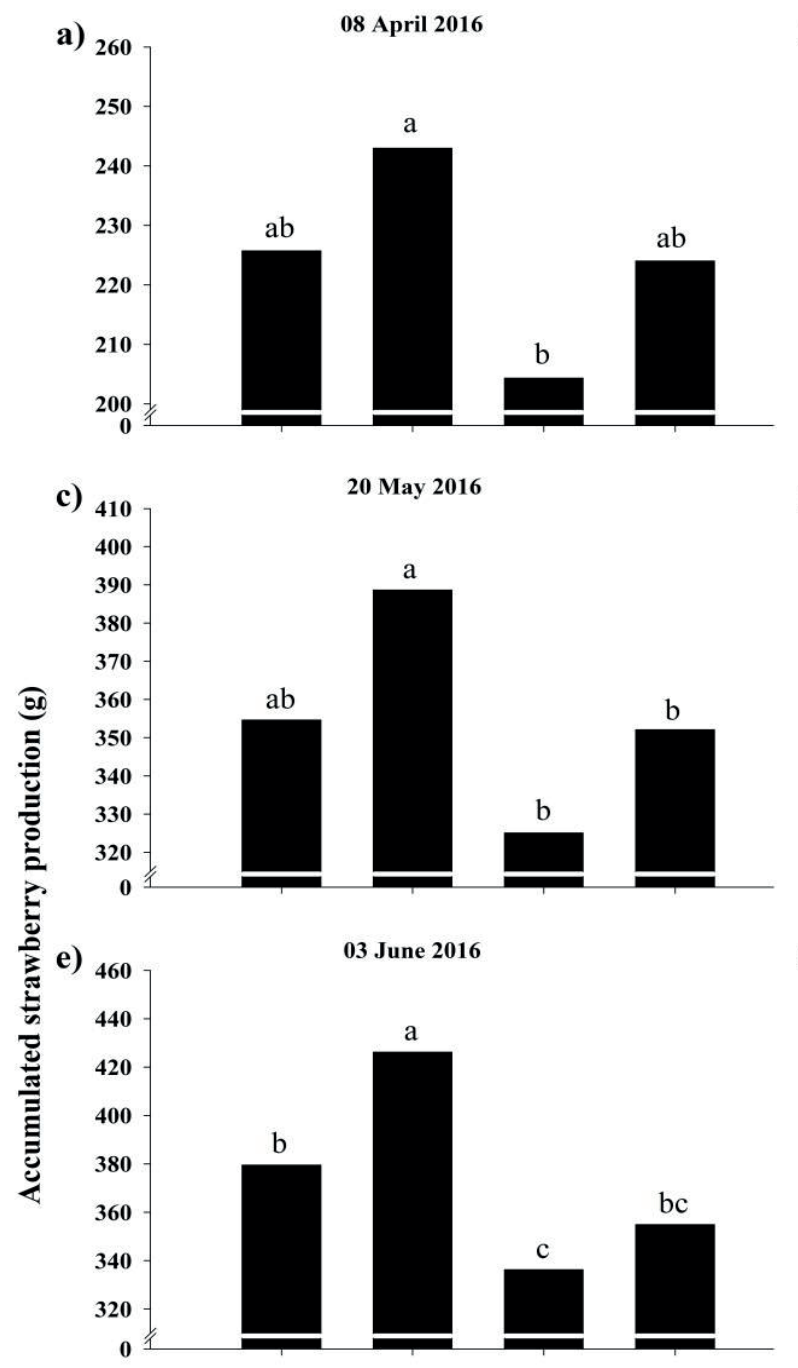

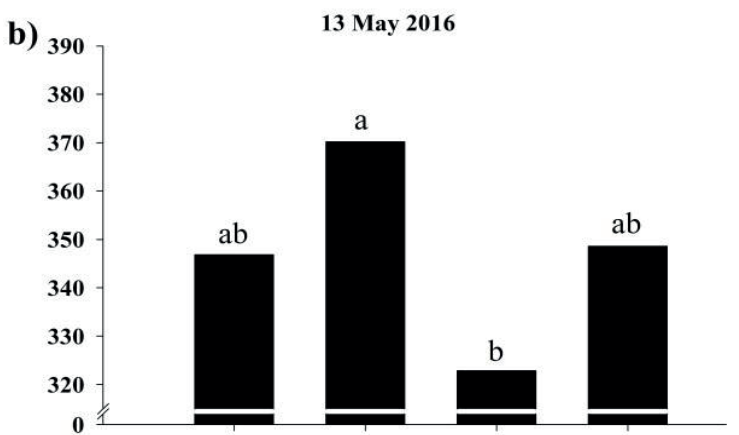

d)

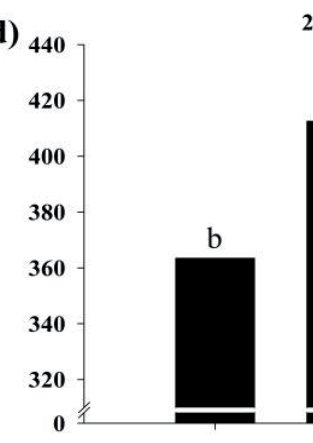

27 May 2016

f)

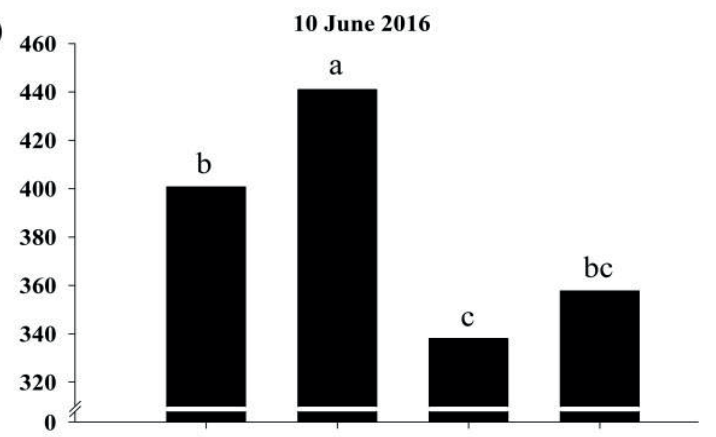

continue 
continuation
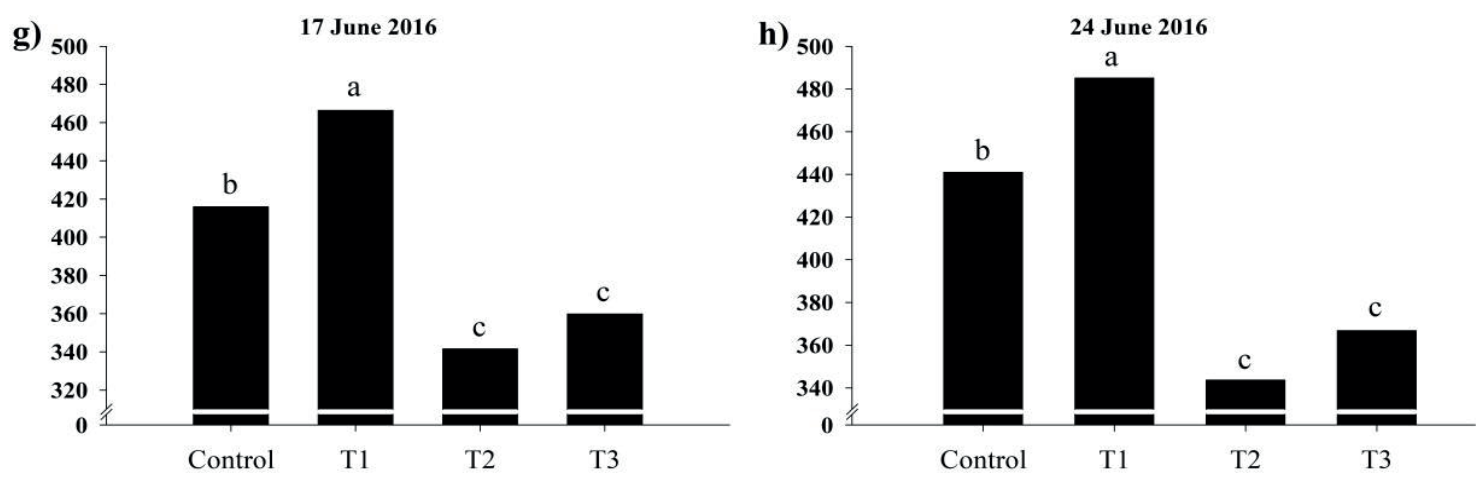

Treatments

Several surveys have reported positive effects of earthworms on plant growth (LAOSSI et al., 2010; PASHANASI et al., 1996; PUGA-FREITAS et al., 2012). This effect can occur in different ways, with increased available nitrogen probably the main factor in this phenomenon, due to the high uptake by the plants and typical low availability in the soil (AGREN et al., 2012). In a meta-analysis, Groenigen et al. (2014) separated the different effects of earthworms on plant productivity, and showed the importance of these invertebrates for release of some forms of nitrogen in the soil $\mathrm{NO}_{3}^{-}$ and $\mathrm{NH}_{4}^{+}$), by comparing experiments with the presence and absence of legume plants. However, the effect of earthworms on soil fertility is dependent on many conditions. Clause et al. (2014) showed an interaction between different species of these invertebrates and soils, and found increases in the total nitrogen in L. terrestris casts.

The presence of earthworms increases microbial activity in soil, an effect that occurs during gut passage, casting, and burrowing (BROWN et al., 2000). When casts are excreted, the high activity of microorganisms elevates the rates of soil organic matter (SOM) mineralization, contributing to the release some nutrients, such as nitrogen and phosphorus (SIMEK; PIZL, 2010). Due to the anoxic environment of the casts, bacterial populations are dominant, and the availability of the reduced form of nitrogen $\left(\mathrm{NH}_{4}^{+}\right)$is higher than oxidized forms
(CHAPUIS-LARDY et al., 2010). Considering the high uptake of nitrogen by strawberry plants and the importance of this element in strawberry production, it is probable the increased availability of this nutrient is utilized for fruit production (ANDRIOLO et al., 2011), minimizing the effects of earthworms on the plant growth observed in other studies when compared with this experiment. Other mechanisms also can explain the positive effects of earthworms on plant productivity. As an example, these invertebrates can stimulate plant symbionts such as arbuscular mycorrhizal fungi (which improve nutrient uptake) and plant growthpromoting bacteria (GORMSEN et al., 2004).

When analyzing the effects of $L$. terrestris inoculation on dry shoot matter (Figure 2) we observed that the presence of earthworms did not influence the negative effects of $F$. oxysporum f. sp. fragariae on strawberry growth. Instead, the inoculation of the pathogen alone or with earthworms produced decreased dry matter, with values of 3.68 and 4.09 for T3 and T2, respectively.

The lack of reduction in the damage caused by F. oxysporum f. sp. fragariae (related to fruit production) following the earthworm inoculation in this experiment was not expected, as normally the positive effects of these invertebrates in the soil negate the negative consequences of plants pathogens (DEMETRIO et al., 2017; LAFONT et 
al., 2007). For example, Stephens et al. (1993) found a reduction of Rhizoctonia solani severity in wheat plants in the presence of Aporrectodea trapezoides. The authors also observed an increase in the shoot dry weight, an effect attributed to an increase in nitrogen content in the soil and possible ingestion of hyphae fungi, which can reduce pathogen populations and roots infections. Lafont et al. (2007) studied the potential of the earthworm Pontoscolex corethrurus as a control for the root-knot nematode Radopholus similis in banana plants and do not observe direct effects on pathogen severity, but their results revealed superior plant growth when earthworms were inoculated. Elmer (2009) evaluated the effects of $L$. terrestris and F. oxysporum on different plant species and verified a $58 \%$ increase in tomato plant weight in the treatment with earthworms. However, the increases in the ammonium/nitrate ratio that usually occurs when earthworms are inoculated also can exacerbate the negative effects of Fusarium wilt in plants (BORRERO et al., 2012). According to Woltz and Jones (1973), increased ammonium content reduced soil $\mathrm{pH}$, improving the development of F. oxysporum.

Figure 2. Effects of Fusarium oxysporum f. sp. fragariae and Lumbricus terrestris in dry strawberry shoot matter at the end of the experimental period. Control (absence of F. oxysporum f. sp. fragariae and earthworms), T1 (absence of F. oxysporum f. sp. fragariae, two L. terrestris per pot), T2 (Inoculum of F. oxysporum f. sp. fragariae, absence of L. terrestris), T3 (Inoculum of F. oxysporum f. sp. fragariae and two L. terrestris per pot). Different letters above bars indicate statistical differences $(\mathrm{p}<0.05)$ by Tukey's test.

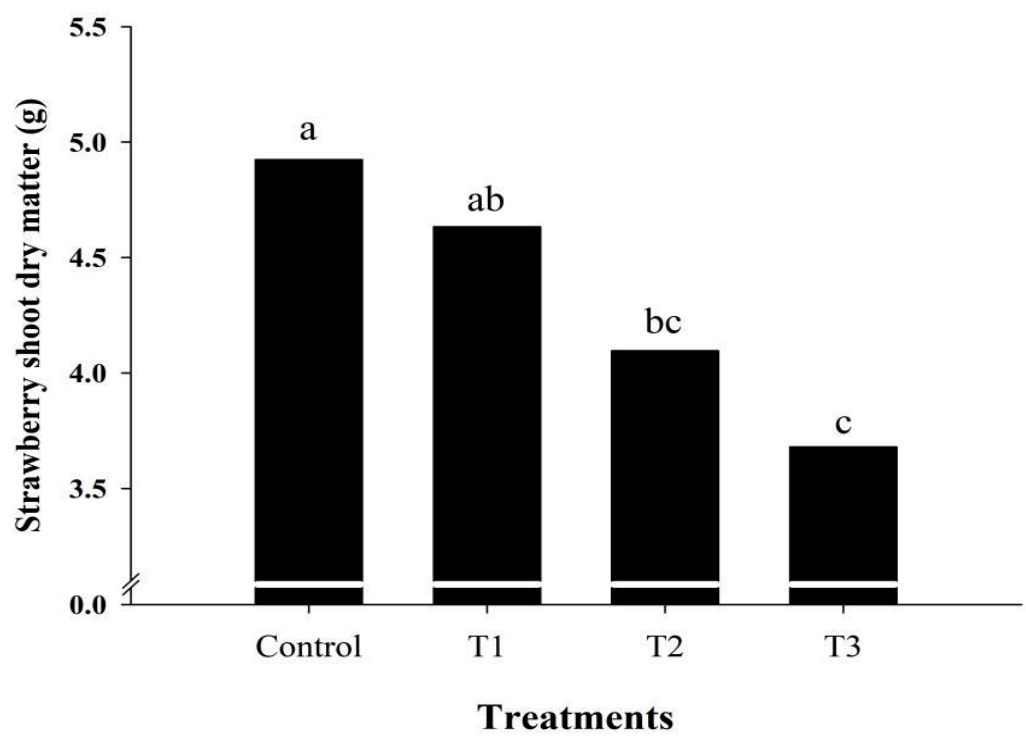

The concentration of nutrients in strawberry leaves was similar among the treatments, and only $\mathrm{Ca}, \mathrm{S}, \mathrm{Mn}$, and $\mathrm{Cu}$ showed statistical differences (Table 2). The values obtained for Ca were higher in T3 $(2.02 \%)$ than control $(1.67 \%)$, but the content of S was greater in $\mathrm{T} 1(0.22 \%)$ compared with $\mathrm{T} 2$ $(0.18 \%)$. The concentrations of Mn were 42.45 and $57.19 \mathrm{mg} \mathrm{kg}^{-1}$ for control and $\mathrm{T} 2$, respectively. $\mathrm{Cu}$ was higher in the treatments with $L$. terrestris inoculation in relation to control. 
Table 2. Nutrient concentration in the leaves of strawberry plants not treated (Control) or treated with: T1 (absence of F. oxysporum f. sp. fragariae, two Lumbricus terrestris per pot); T2 (Inoculum of F. oxysporum f. sp. fragariae, absence of $L$. terrestris); T3 (Inoculum of $F$. oxysporum f. sp. fragariae and two L. terrestris per pot).

\begin{tabular}{|c|c|c|c|c|c|}
\hline \multirow{2}{*}{$\begin{array}{l}\text { Nutrient } \\
\text { Content }\end{array}$} & & \multicolumn{4}{|c|}{ Treatments } \\
\hline & & Control & T1 & $\mathrm{T} 2$ & T3 \\
\hline $\mathrm{N}$ & \multirow{6}{*}{$\partial^{\circ}$} & $2.38^{\mathrm{ns}}$ & $2.59^{\mathrm{ns}}$ & $2.53^{\mathrm{ns}}$ & $2.52^{\mathrm{ns}}$ \\
\hline$P$ & & $0.37^{\mathrm{ns}}$ & $0.46^{\mathrm{ns}}$ & $0.41^{\mathrm{ns}}$ & $0.46^{\mathrm{ns}}$ \\
\hline $\mathrm{K}$ & & $0.44^{\mathrm{ns}}$ & $0.46^{\mathrm{ns}}$ & $0.39^{\mathrm{ns}}$ & $0.45^{\mathrm{ns}}$ \\
\hline $\mathrm{Ca}$ & & $1.67 \mathrm{~b}$ & $1.74 a b$ & $1.92 \mathrm{ab}$ & $2.02 a$ \\
\hline $\mathrm{Mg}$ & & $0.54^{\mathrm{ns}}$ & $0.56^{\mathrm{ns}}$ & $0.59^{\mathrm{ns}}$ & $0.57^{\mathrm{ns}}$ \\
\hline $\mathrm{S}$ & & $0.21 \mathrm{ab}$ & $0.22 a$ & $0.18 b$ & $0.21 \mathrm{ab}$ \\
\hline $\mathrm{Na}$ & \multirow{6}{*}{ 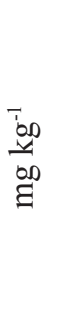 } & $60.82^{\text {ns }}$ & $136.08^{\mathrm{ns}}$ & $89.97^{\mathrm{ns}}$ & $96.06^{\mathrm{ns}}$ \\
\hline $\mathrm{Fe}$ & & $78.85^{\text {ns }}$ & $76.57^{\mathrm{ns}}$ & $87.78^{\text {ns }}$ & $100.78^{\text {ns }}$ \\
\hline $\mathrm{Mn}$ & & $42.45 b$ & $44.00 \mathrm{~b}$ & 57.19a & 49.09ab \\
\hline $\mathrm{Zn}$ & & $26.20^{\mathrm{ns}}$ & $29.63^{\text {ns }}$ & $27.21^{\mathrm{ns}}$ & $30.61^{\mathrm{ns}}$ \\
\hline $\mathrm{Cu}$ & & $4.90 \mathrm{~b}$ & $6.05 a$ & 4.93ab & $6.03 a$ \\
\hline $\mathrm{B}$ & & $21.78^{\mathrm{ns}}$ & $20.20^{\mathrm{ns}}$ & $19.34^{\mathrm{ns}}$ & $18.90^{\mathrm{ns}}$ \\
\hline
\end{tabular}

Different letters indicate statistical differences $(\mathrm{p}<0.05)$ by Tukey's test.

${ }^{\text {ns }}$ non-significant $(\mathrm{p}<0.05)$ differences.

The previously cited effects of earthworms on SOM mineralization can increase the availability of these metals, due to the release of elements before being adsorbed in organic-metal interactions, increasing the uptake by strawberry plants. Additionally, the production of $\mathrm{CaCO}_{3}$ in the calciferous glands can change $\mathrm{pH}$ in the casts, also modifying the availability of some metals (EDWARDS, 2004; SHUMAN, 1999). Cheng and Wong (2002) observed an increase of some fractions of extractable $\mathrm{Zn}$ in the soil when Pheretima sp. were inoculated. Similar results are cited by Wen et al. (2004) for $\mathrm{Cr}, \mathrm{Zn}$, and $\mathrm{Cu}$ in the presence of earthworms. Although the foliar content of Mn had changed in our study between the treatments, this micronutrient normally presents higher variations in strawberry plants, with values around 30-350 mg kg-1 (MILLS; BENTON JONES, 1996). On the other hand, the increase in Mn content may have resulted from a physiological response of the plant to pathogen attack, since this element acts as an enzymatic activator of many enzymes, such as dehydrogenases, transferases, hydroxylases and decarboxylases (BURNELL, 1988), related to the immunophysiological defense system of the plant (ELMER; DATNOFF, 2014).

\section{Conclusion}

In this work, the earthworm Lumbricus terrestris was unable to suppress the negative effects of Fusarium oxysporum f. sp. fragariae on strawberry production and shoot dry matter. However, in the treatments without pathogen inoculation, the presence of earthworms increased plant productivity.

\section{Acknowledgments}

Thanks to the Coordination for the Improvement of Higher Level Personnel (CAPES) for the postdoctoral opportunity in Seville University, Spain.

\section{References}

AGREN, G. I.; WETTERSTEDT, J. Å. M.; BILLBERGER, M. F. K. Nutrient limitation on terrestrial 
plant growth - modeling the interaction between nitrogen and phosphorus. New Phytologist, Oxford, v. 194, n. 1, p. 953-960, 2012.

ANDRIOLO, J. L.; ERPEN, L.; CARDOSO, F. L.; COCCO, C.; CASAGRANDE, G. S.; JÄNISCH, D. I. Nitrogen levels in the cultivation of strawberries in soilless culture. Horticultura Brasileira, Brasília, v. 29, n. 4, p. 516-519, 2011.

AUSTRALIAN STANDARD. AS 3743-1993 Potting mixes. Standard Association of Australia. Sydney: SAI Global Limited, 1993. Available at: <www.saiglobal. com>. Accessed at: 6 july 2017.

BORRERO, C.; BASCÓN, J.; GALLARDO, M. Á.; ORTA, M. S.; AVILÉS, M. New foci of strawberry Fusarium wilt in Huelva (Spain) and susceptibility of the most commonly used cultivars. Scientia Horticulturae, Amsterdam, v. 226, n. 1, p. 85-90, 2017.

BORRERO, C.; TRILlAS, I.; AVILÉS, M. Carnation Fusarium wilt suppression in four composts. European Journal of Plant Pathology, Dordrecht, v. 123, n. 1, p. 425-433, 2009.

BORRERO, C.; TRILlAS, M. I.; DELGADO, A.; AVILÉS, M. Effect of ammonium/nitrate ratio in nutrient solution on control of Fusarium wilt of tomato by Trichoderma asperellum T34. Plant Pathology, Chichester, v. 61, n. 1, p. 132-139, 2012.

BROWN, G. G.; BAROIS, I.; LAVELLE, P. Regulation of soil organic matter dynamics and microbial activity in the drilosphere and the role of interactions with other edaphic functional domains. European Journal of Soil Biology, Paris, v. 36, n. 3-4, p. 177-198, 2000.

BURNELL, J. N. The biochemistry of manganese in plants. In: GRAHAN, R. D.; HANNAM, R. J.; UREN, N. C. (Ed.). Manganese in soil and plants. Dordrecht: Kluwer Academic Publishers, 1988. p. 125-137.

CHAPUIS-LARDY, L.; BRAUMAN, A.; BERNARD, L.; PABLO, A. L.; TOUCET, J.; MANO, M. J.; WEBER, L.; BRUNET, D.; RAZAFIMBELO, T.; CHOTTE, J. L.; BLANCHART, E. Effect of the endogeic earthworm Pontoscolex corethrurus on the microbial structure and activity related to $\mathrm{CO}_{2}$ and $\mathrm{N}_{2} \mathrm{O}$ fluxes from a tropical soil (Madagascar). Applied Soil Ecology, Amsterdam, v. 45, n. 3, p. 201-208, 2010.

CHENG, J.; WONG, M. H. Effects of earthworms on $\mathrm{Zn}$ fractionation in soils. Biology and Fertility of Soils, Berlin, v. 36, n. 1, p. 72-78, 2002.

CLAUSE, J.; BAROT, S.; RICHARD, B.; DECAËNS, T.; FOREY, E. The interactions between soil type and earthworm species determine the properties of earthworm casts. Applied Soil Ecology, Amsterdam, v. 83, n. 1, p.
149-158, 2014.

CRITTENDEN, S. J.; ESWARAMURTHY, T.; GOEDE, R. G. M. de; BRUSSAARD, L.; PULLEMAN, M. M. Effect of tillage on earthworms over short- and mediumterm in conventional and organic farming. Applied Soil Ecology, Amsterdam, v. 83, n. 1, p. 140-148, 2014.

DEMETRIO, W. C.; DIONÍSIO, J. A.; MACEDA, A. Earthworms and root-knot nematodes: effect on soil biological activity and tomato growth. Semina: Ciências Agrárias, Londrina, v. 38, n. 4, p. 2449-2462, 2007.

EDWARDS, C. A. Earthworm ecology. $2^{\text {th }}$ ed. Florida: CRC Press, 2004. 448 p.

ELMER, W. H. Influence of earthworm activity on soil microbes and soil-borne diseases of vegetables. Plant Disease, St. Paul, v. 93, n. 2, p. 175-179, 2009.

ELMER, W.; DATNOFF, L. Mineral nutrition and suppression of plant disease. In: VAN ALFEN, N. K. (Ed.). Encyclopedia of agriculture and food systems. San Diego: Elsevier, 2014. v. 4, p. 231-244.

FANG, X.; PHILLIPS, D.; LI, H.; SIVASITHAMPARAM, K.; BARBETTI, M. J.; BARBETTI, M. J. Comparisons of virulence of pathogens associated with crown and root diseases of strawberry in Western Australia with special reference to the effect of temperature. Scientia Horticulturae, Amsterdam, v. 131, n. 1, p. 39-48, 2011.

FOOD AND AGRICULTURE ORGANIZATION OF THE UNITED NATIONS- FAO. Crop production Strawberry. Rome: FAO, 2017. Available at: <http:// www.fao.org/faostat/en/\#data/QC $>$. Accessed at: 6 july 2017.

GOLZAR, H.; PHILLIPS, D.; MACK, S. Occurrence of strawberry root and crown rot in Western Australia. Australasian Plant Disease Notes, Sydney, v. 2, n. 1965, p. 145-147, 2007.

GORMSEN, D.; OLSSON, P. A.; HEDLUND, K. The influence of collembolans and earthworms on AM fungal mycelium. Applied Soil Ecology, Amsterdam, v. 27, n. 1, p. 211-220, 2004.

GROENIGEN, J. van; LUBBERS, I. M.; VOS, H. M. J.; BROWN, G. G.; DEYN, G. B. de; GROENIGEN, K. J. van. Earthworms increase plant production: a metaanalysis. Scientific Reports, London, v. 4, n. 1, p. 1-7, 2014.

KOIKE, S. T.; GORDON, T. R. Management of Fusarium wilt of strawberry. Crop Protection, Guildford, v. 73, n. 1, p. 67-72, 2015.

KUKKONEN, S.; PALOJÄNRVI, A.; RÄKKÖLÄINEN, M.; VESTBERG, M. Cropping history and peat amendment-induced changes in strawberry field 
earthworm abundance and microbial biomass. Soil Biology and Biochemistry, Oxford, v. 38, n. 1, p. 21522161, 2006.

LAFONT, A.; RISÈDE, J. M.; LORANGERMERCIRIS, G.; CLEMORNT-DAUPHIN, C.; DOREL, M.; RHINO, B.; LAVELLE, O. Effects of the earthworm Pontoscolex corethrurus on banana plants infected or not with the plant-parasitic nematode Radopholus similis. Pedobiologia, Jena, v. 51, n. 1, p. 311-318, 2007.

LAOSSI, K.-R.; GIONOT, A.; NOGUERA, D.; BLOUIN, M.; BAROT, S. Earthworm effects on plant growth do not necessarily decrease with soil fertility. Plant and Soil, The Hague, v. 328, n. 1-2, p. 109-118, 2010.

LAVELLE, P.; BIGNELL, D.; LEPAGE, M.; WOLTER, V.; ROGER, P.; INESON, P.; HEAL, O. W.; DHILLION, $\mathrm{S}$. Soil function in a changing world: the role of invertebrate ecosystem engineers. European Journal of Soil Biology, Paris, v. 33, n. 4, p. 159-193, 1997.

MILLS, H. A.; BENTON JONES, J. Plant analysis handbook II: a practical sampling, preparation, analysis, and interpretation guide. Athens: MicroMacro Publishing, 1996. 422 p.

MORENO, A. G. Lombrices de tierra: material y métodos. In: MORENO, A. G.; BORGES, S. (Ed.). Avances en taxonomía de lombrices de tierra. Madrid: Editorial Complutense y Obra Social Caja, 2004. p. 2538.

MURPHY, J.; RILEY, J. A modified single solution method for the determination of phosphate in natural waters. Analytical Chimica Acta, Amsterdam, v. 27, n. 1, p. 31-36, 1962.

PASHANASI, B.; LAVELLE, P.; ALEGRE, J.; CHARPENTIER, F. Effect of the endogeic earthworm Pontoscolex corethrurus on soil chemical characteristics and plant growth in a low-input tropical agroecosystem. Soil Biology and Biochemistry, Oxford, v. 28, n. 6, p. 801-810, 1996.

PUGA-FREITAS, R.; BAROT, S.; TACONNAT, L.; RENOU, J.-P.; BLOUIN, M. Signal molecules mediate the impact of the earthworm Aporrectodea caliginosa on growth, development and defense of the plant Arabidopsis thaliana. PLoS ONE, San Francisco, v. 7, n. 12, p. 1-10, 2012.

RUTGERS, M.; ORGIAZZI, A.; GARDI, C.; RÖMBKE, J.; JÄNSCH, S.; KEITH, A. M.; NEILSON, R.; BOAG, B.; SCHMIDT, O.; MURCHIE, A. K.; BLACKSHAW, R. P.; PÉRÈS, G.; CLUZEAU, D.; GUERNION, M.; BRIONES, M. J. I.; RODEIRO, J.; PIÑEIRO, R.; COSÍN, D. J. D.; SOUSA, J. P.; SUHADOLC, M.;
KOS, J.; KROGH, P. H.; FABER, J. H.; MULDER, C.; BOGTE, J. B.; WIJNEN, H. J. van; SCHOUTEN, A. J.; ZWART, D. de. Mapping earthworm communities in Europe. Applied Soil Ecology, Amsterdam, v. 97, n. 1, p. 98-111, 2016.

SHUMAN, L. M. Organic waste amendments effect on zinc fractions of two soils. Journal of Environmental Quality, Madison, v. 28, n. 1, p. 1442-1447, 1999.

SIMEK, M.; PIZL, V. Soil $\mathrm{CO}_{2}$ flux affected by Aporrectodea caliginosa earthworms. Central European Journal of Biology, Berlin, v. 5, n. 3, p. 364-370, 2010.

STATSOFT. INC. Statistica. Data Analysis Software System. version 10. Palo Alto: TIBCO Software, 2011. Available at: $<w w w . s t a t s o f t . c o m>$. Accessed at: 6 july 2017.

STEPHENS, P. M.; DAVOREN, C. W.; DOUBE, B. M.; RYDER, M. H.; BENGER, A. M.; NEATE, S. M. Reduced severity of Rhizoctonia solani disease on wheat seedlings associated with the presence of the earthworm Aporrectodea trapezoides (Lumbricidae). Soil Biology and Biochemistry, Oxford, v. 25, n. 11, p. 1477-1484, 1993.

STRAUSS, S. L.; KLUEPFEL, D. A. Anaerobic soil disinfestation: a chemical-independent approach to preplant control of plant pathogens. Journal of Integrative Agriculture, Beijing, v. 14, n. 11, p. 2309-2318, 2015.

SUGA, H.; HIRAYAMA, Y.; MORISHIMA, M.; SUZUKI, T.; KAGEYAMA, K.; HYAKUMACHI, M. Development of PCR Primers to identify Fusarium oxysporum f. sp. fragariae. Plant Disease, St. Paul, v. 97, n. 1, p. 619-625, 2013.

SYSTAT SOFTWARE. INC. SigmaPlot for Windows, version 11. San Jose: Cranes, 2008. Available at: <www. systatsoftware.com>. Accessed at: 6 july 2017.

TUITERT, G.; SZCZECH, M.; BOLlEN, G. J. Suppression of Rhizoctonia solani in potting mixtures amended with compost made from organic household waste. Phytopathology, Saint Paul, v. 88, n. 8, p. 764$773,1998$.

WEN, B.; HU, X.; LIU, Y.; WANG, W.; FENG, M.; SHAN, X. The role of earthworms (Eisenia fetida) in influencing bioavailability of heavy metals in soils. Biology and Fertility of Soils, Berlin, v. 40, n. 1, p. 181$187,2004$.

WOLTZ, S. S.; JONES, J. P. Interactions in source of nitrogen fertilizer and liming procedure in the control of Fusarium wilt of tomato. Hortscience, St. Joseph, v. 8, n. 1, p. 137-138, 1973. 